\title{
FAKTOR-FAKTOR YANG MEMPENGARUHI KEPUTUSAN PENGGUNAAN OVO PADA MAHASISWA FAKULTAS EKONOMI UNIVERSITAS NEGERI YOGYAKARTA
}

\author{
Rinda Novitasari \& Supriyanto \\ Universitas Negeri Yogyakarta, Indonesia \\ rinda.novitasari2016@student.uny.ac.id, supriyanto@uny.ac.id
}

\begin{abstract}
Abstrak: Penelitian ini bertujuan untuk mengetahui faktor-faktor yang mempengaruhi keputusan penggunaan OVO pada mahasiswa Fakultas Ekonomi Universitas Negeri Yogyakarta secara parsial maupun simultan. Faktor-faktor yang diteliti dalam penelitian ini yaitu gaya hidup, persepsi, kepercayaan, dan promosi. Penelitian ini termasuk dalam penelitian asosiatif dengan pendekatan kuantitatif. Populasi dalam penelitian ini yaitu seluruh mahasiswa S1 Fakultas Ekonomi Universitas Negeri Yogyakarta angkatan 20162019 yang pernah dan sedang menggunakan OVO. Teknik pengambilan sampel dengan menggunakan purposive sampling dengan jumlah sampel sebanyak 250 orang. Teknik analisis data menggunakan analisis regresi linier berganda. Hasil penelitian menunjukkan bahwa terdapat pengaruh positif dan signifikan gaya hidup, persepsi, kepercayaan dan promosi secara parsial dan simultan terhadap keputusan penggunaan OVO pada mahasiswa Fakultas Ekonomi Universitas Negeri Yogyakarta. Keputusan penggunaan OVO pada mahasiswa Fakultas Ekonomi Universitas Negeri Yogyakarta dipengaruhi oleh keempat variabel bebas tersebut sebesar $46,1 \%$ dan sisanya $53,9 \%$ dipengaruhi oleh variabel lain yang tidak diteliti dalam penelitian ini.
\end{abstract}

Kata kunci: Gaya hidup, Persepsi, Kepercayaan, Promosi, Keputusan Penggunaan OVO

\section{THE FACTORS THAT INFLUENCE THE DECISION TO USE OVO IN STUDENTS OF THE FACULTY OF ECONOMICS YOGYAKARTA STATE UNIVERSITY}

\begin{abstract}
The study aimed to determine the factors that influence the decision to use OVO in students of the Faculty of Economics at Yogyakarta State University both partially and simultaneously. The factors examined in this study are lifestyle, perception, trust, and promotion. This study was included in an associative survey with a quantitative approach. Population in this study were all undergraduate students of the Faculty of Economics Yogyakarta State University class of 2016-2019 who have and are currently using OVO. The sampling technique using purposive sampling technique with a total sample of 250 respondent. Data analysis technique was linear regression analysis. The result of the study showed that there was a positive and significant effect of lifestyle, perception, trust, and promotion as a partial and simultaneous decision to use OVO. The decision to use OVO on students of the Faculty Economics Yogyakarta State University was affected by the four independent variables by $46,1 \%$. In contrast, the remaining $53,9 \%$ is affected by other variables, not under study.
\end{abstract}

Keywords: Lifestyle, Perception, Trust, Promotion, Decision to Use OVO

\section{PENDAHULUAN}

Perkembangan teknologi dan informasi di era revolusi 4.0 semakin melesat tinggi. Perkembangan teknologi dan informasi telah menyebabkan perubahan pada berbagai bidang baik sosial, ekonomi, pendidikan, maupun budaya yang berlangsung dengan cepat. Hal ini didukung dengan adanya kemudahan dalam mengakses teknologi dan informasi dari berbagai penjuru dunia. Teknologi dan informasi tersebut dapat diakses oleh siapa saja dan di mana saja dengan adanya dukungan media internet. 
Internet merupakan jaringan komunikasi elektronik yang menghubungkan jaringan komputer yang terorganisasi di seluruh dunia melalui satelit. Saat ini, internet menjadi sesuatu yang tidak dapat dihindari oleh individu di berbagai negara terutama negara Indonesia. Perkembangan internet di Indonesia disambut baik oleh masyarakat. Hal ini dibuktikan dengan adanya peningkatan jumlah pengguna internet dari tahun ke tahun berdasarkan data APJII (Asosiasi Penyelenggara Jasa Internet) tahun 2019 (APJII, 2019), sebagaimana terlihat pada gambar 1.

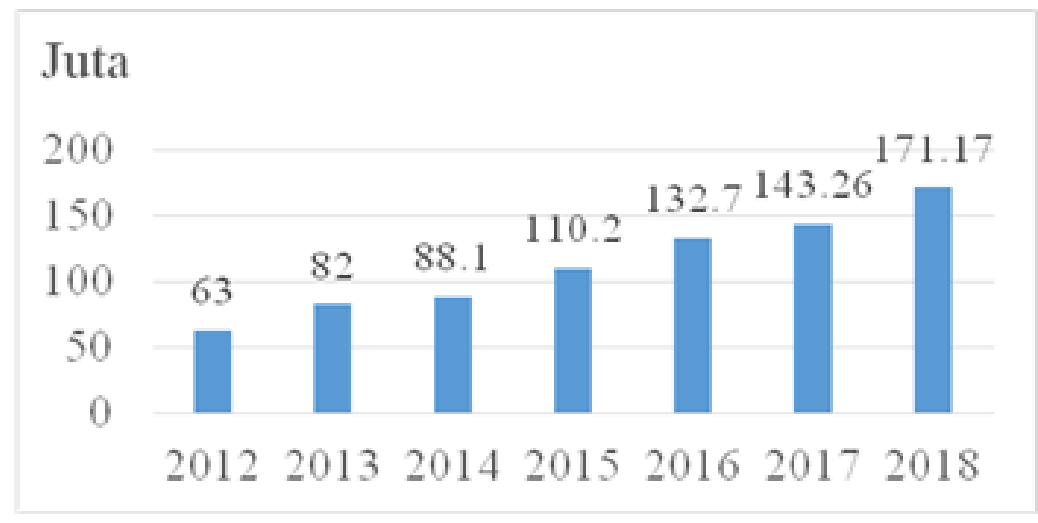

Sumber: APJII2019

Gambar 1. Pertumbuhan Pengguna Internet di Indonesia Tahun 2012-2018

Berdasarkan data Asosiasi Penyelenggara Jasa Internet Indonesia 2019 (APJII, 2019) pertumbuhan pengguna internet dari tahun ke tahun mengalami peningkatan yang sangat pesat. Pada tahun 2015 pengguna internet di Indonesia sebanyak 110,2 juta jiwa, tahun 2016 sebanyak 132,7 juta jiwa, tahun 2017 sebanyak 143,26 juta jiwa, dan tahun 2018 sebanyak 171,17 juta jiwa. Pengguna internet terkadang tidak hanya mengakses internet dengan komputer atau smartphone tetapi juga mengakses dari kedua perangkat tersebut.

Beberapa tahun yang lalu, internet hanya digunakan untuk berkomunikasi dan mencari informasi secara online. Namun pada saat ini, perkembangan penggunaan internet tentu sudah tidak terbendung lagi. Di Indonesia mengalami perkembangan penggunaan internet dalam hal sistem pembayaran. Sistem pembayaran menggunakan uang secara langsung (cash) sekarang berkembang menjadi pembayaran non tunai. Perkembangan tersebut menyebabkan terdapat masyarakat yang memilih melakukan transaksi menggunakan kartu ATM, kartu kredit, cek maupun menggunakan uang elektronik (e-money) dibanding menggunakan uang cash. Hal ini mengarah pada budaya cashless society yang semakin marak digencarkan pada saat ini terutama pada produk uang elektronik (e-money).

Bank Indonesia (Bank Indonesia, 2018) menyatakan bahwa e-money merupakan alat pembayaran dalam bentuk elektronik di mana uangnya dapat disimpan dalam media elektronik tertentu. Media elektronik yang dapat digunakan untuk menyimpan nilai uang elektronik dapat berupa chip (berbasis chip) yang bentuknya seperti kartu ATM dan berbasis server yaitu aplikasi 
yang dapat diunduh melalui PlayStore. Saat ini, e-money yang berkembang di Indonesia banyak macamnya. Berdasarkan data Bank Indonesia per 27 Mei 2020 terkait Informasi Perizinan Penyelenggara dan Pendukung Jasa Sistem Pembayaran terdapat 41 jenis uang elektronik yang beredar di Indonesia (Bank Indonesia, 2020). Uang elektronik yang beredar di Indonesia berbasis server yaitu MYNTE-money, Sakuku, Rekening Ponsel, Jak One, Mandiri e-cash, Mega Virtual, Unik Qu, Nobu E-money, BBM Money, T-Bank, Finn Channel, PayPro (Dompetku), DokuPay, Sky E-Mobile Money, Flexy Cash, T-Cash, XL Tunai, Uangku, Go-Pay, Truemoney, Dana, Dooet, Gudang Voucher, Speed Cash, OVO, iSaku, Paytren tahun 2018, KasPro (Payu), Bluepay Cash tahun 2018, Eze E-link, M-Bayar tahun 2018, Duwit, Shopeepay, Simas E-money, Otto Cash, LinkAja, Zipay, PAC Cash, Pay Dia, dan Netzme (Bank Indonesia, 2020).

Berdasarkan data katadata.co.id pada awal tahun 2020 menyebutkan bahwa OVO memiliki pangsa pasar mencapai 37\% dari total transaksi dompet digital di Indonesia tahun 2019 (Aria, 2019). Go-Pay mencapai 17\%, Dana mencapai 10\% , dan LinkAja mencapai 3\% dari total transaksi tahun 2019 yang mencapai Rp 56,1 triliun. Berdasarkan data tersebut OVO disebut sebagai uang elektronik yang memiliki nilai transaksi terbesar di Indonesia pada tahun 2019.

OVO merupakan bentuk inovasi fintech (financial technology) dalam sistem pembayaran yang digunakan pada transportasi online atau ojek online. OVO dapat digunakan pada layanan pada Grab dan Tokopedia. Selain layanan pada aplikasi ojek online, OVO juga bekerjasama dengan beberapa UMKM yang ada di Indonesia. Pembayaran untuk pembelian barang dari konsumen ke UMKM yang bekerjasama dapat dilakukan dengan OVO. Seorang konsumen harus memiliki saldo OVO agar dapat bertransaksi atau membayar dengan menggunakan uang elektronik tersebut. Saldo OVO dapat diperoleh dengan sistem Top up.

Top up yaitu mengisi saldo OVO dengan cara membeli atau menukarkan sejumlah uang tertentu agar dapat digunakan untuk bertransaksi. Apabila seseorang tidak melakukan Top up saldo OVO, seseorang tidak akan bisa melakukan transaksi menggunakan OVO tersebut walaupun seseorang tersebut memiliki aplikasi e-money tersebut. Top up OVO dapat dilakukan dengan beberapa macam pilihan cara Top up yaitu Top up melalui bank, Top up melalui merchant, dan Top up melalui driver ojek online.

Perkembangan transaksi OVO yang pesat dikarenakan banyaknya yang menggunakan OVO sebagai uang elektronik yang digunakan sebagai pembayaran mereka. Hal ini dikarenakan adanya keuntungan yang akan diperoleh bagi pengguna OVO. Menurut Bothun (Bothun et al., 2013) dalam penelitiannya, terdapat beberapa keuntungan yang dapat membuat masyarakat memilih untuk menggunakan mobile payment. Keuntungan yang dapat diperoleh oleh pengguna yaitu kemudahan dalam melakukan transaksi dan dapat lebih berhemat. Hal ini dikarenakan perusahaan memberikan promosi terhadap pengguna e-money dengan voucher maupun diskon dari jasa yang ditawarkan. 
Di sisi lain, OVO yang berkembang pesat ternyata tidak lantas menyebabkan semua orang langsung merubah gaya hidupnya untuk menggunakan OVO. Ada orang yang tidak langsung beralih menggunakan OVO. Mereka lebih memilih untuk bertransaksi cash dengan uang secara langsung daripada menggunakan OVO. Hal ini dikarenakan kurangnya sosialisasi langsung terkait penggunaan OVO. Sosialisasi lebih sering dilakukan media elektornik maupun media online seperti youtube sehingga seseorang tidak semuanya mengetahui mengenai penggunaan e-money. Selain itu, orang tidak langsung menggunakan OVO dikarenakan adanya jenis uang elektronik lain yang mereka pilih.

Berdasarkan review negatif pengguna OVO yang ada di ulasan dan rating di PlayStore terdapat banyak keluhan terkait OVO. Keluhan OVO seperti aplikasi yang sering error saat digunakan dan dalam memuat laman fitur layanan membutuhkan waktu yang lama menyebabkan seseorang khawatir dan ragu untuk menggunakan OVO. Selain itu, Top up saldo OVO yang tidak masuk dan saldo OVO berkurang sendiri tanpa adanya sebuah transaksi menyebabkan seseorang tidak percaya untuk menggunakan OVO. Maraknya penipuan yang dilakukan kepada pengguna OVO juga dapat menyebabkan ketidakpercayaan untuk menggunakan OVO. Promosi yang tidak dapat diperoleh oleh seseorang (promo, diskon, cashback) menyebabkan seseorang kurang tertarik menggunakan OVO.

Perkembangan OVO juga dirasakan oleh semua kalangan masyarakat terutama kalangan mahasiswa. Mahasiswa merupakan kalangan masyarakat yang paling dekat dengan perkembangan teknologi dan informasi. Perkembangan tersebut dapat diterima oleh mahasiswa dengan mudah dan cepat termasuk perkembangan OVO. Mahasiswa juga datang dari background yang berbeda. Oleh karena itu, mahasiswa dianggap lebih pantas digunakan sebagai subjek dalam penelitian ini.

Mahasiswa yang dipilih oleh peneliti menjadi subjek penelitian yaitu mahasiswa Fakultas Ekonomi Universitas Negeri Yogyakarta. Hal ini dikarenakan mahasiswa tersebut aktivitasnya lebih dekat dengan peneliti sehingga peneliti dapat melakukan penelitian yang lebih mendalam. Mahasiswa Fakultas Ekonomi Universitas Negeri Yogyakarta juga dianggap lebih kritis daripada mahasiswa fakultas lain karena memiliki bekal ilmu ekonomi. Peneliti melakukan pra survei pada 50 mahasiswa Fakultas Ekonomi Universitas Negeri Yogyakarta. Pra survei tersebut menunjukkan hasil bahwa 37 atau 74\% mahasiswa pernah menggunakan OVO. Mahasiswa yang pernah menggunakan OVO mengatakan bahwa bertransaksi menggunakan OVO lebih praktis dan efisien daripada menggunakan uang cash karena dapat menghemat waktu dan dapat membayar dengan uang pas tanpa kembalian. Selain itu, banyak keuntungan yang diperoleh ketika menggunakan OVO. Di sisi lain, banyak kekhawatiran dan kendala yang dirasakan oleh mahasiswa ketika menggunakan OVO seperti Top up yang tidak masuk, saldo yang berkurang tanpa adanya transaksi, terjadinya penipuan, peyalahgunaan identitas, dan promo yang tidak mesti didapatkan oleh semua orang. Selain itu, mahasiswa juga merasa khawatir ketika saldo 
OVO tidak bisa digunakan untuk transfer ke sesama OVO maupun bank karena belum OVO premier. Hal ini dikarenakan pengurusan OVO premier yang hanya bisa dilakukan di kios OVO dan di Yogyakarta belum ada kios OVO sehingga menyebabkan mahasiswa harus pergi ke daerah yang ada kios OVO seperti Semarang, Surabaya, Bandung, Jakarta, dan lain-lain. Mahasiswa yang tidak menggunakan OVO sebesar $26 \%$ atau 13 mahasiswa menyatakan bahwa menggunakan OVO terlalu ribet daripada menggunakan cash termasuk dalam hal Top up, pengurusan OVO premier yang harus ke kios OVO, rumah yang tidak terjangkau dengan layanan OVO menyebabkan tidak tertariknya menggunakan OVO.

Terdapat beberapa faktor yang menyebabkan individu untuk memutuskan menggunakan atau tidak menggunakan OVO. Menurut Kotler dan Amstrong (Kotler dan Amstrong, 2013) faktor yang menyebabkan keputusan penggunaan yaitu 1) faktor budaya budaya yang terdiri dari subbudaya dan kelas sosial, 2) faktor sosial yang terdiri dari kelompok, keluarga, dan peran dan status, 3) faktor pribadi yan terdiri dari usia dan tahap siklus hidup, pekerjaan, situasi ekonomi, gaya hidup, kepribadian dan konsep diri, dan 4) faktor psikologis yang terdiri dari motivasi, persepsi, pembelajaran, kepercayaan dan sikap. Dalam penelitian ini, peneliti tertarik untuk meneliti mengenai faktor gaya hidup, persepsi, keyakinan dan promosi terhadap penggunaan OVO.

Faktor yang mempengaruhi keputusan seseorang untuk menggunakan OVO adalah gaya hidup. Kotler dan Keller (Kotler \& Keller, 2009) menyatakan gaya hidup merupakan pola hidup diekspresikan dalam bentuk aktivitas, minat, dan pendapat oleh seseorang di dunia ini . Solomon (Solomon, 2012) menyatakan bahwa gaya hidup ialah pola konsumsi yang mencerminkan pilihan seseorang dalam hal bagaimana menghabiskan uang dan waktu. Gaya hidup seseorang tidak akan bersifat permanen dan cepat berubah seperti halnya perubahan gaya hidup dengan bertransaksi menggunakan OVO.

Selain itu, adanya faktor persepsi akan mempengaruhi seseorang untuk menggunakan $e$ money. Saputra dan Samuel (Saputra \& Semuel, 2013) menyatakan bahwa persepsi merupakan proses di mana seseorang memilih, mengorganisasi, dan mengartikan masukan informsai untuk menciptakan suatu gambaran tentang kehidupan. Persepsi positif terhadap OVO menyebabkan seseorang menggunakan OVO.

Selain itu, faktor lainnya yaitu kepercayaan. Mowen dan Minor (Mowen \& Minor, 2002) menyatakan bahwa kepercayaan ialah semua pengetahuan konsumen dan seluruh kesimpulan kesimpulan yang dibuat konsumen mengenai objek, atribut dan manfaatnya. Maksud dari objek di sini adalah dalam bentuk produk atau jasa, orang, perusahaan dan segala sesuatu yang menyebabkan seseorang mempunyai kepercayaan dan sikap.

Selain itu, faktor lainnya yaitu promosi. Menurut Lupiyoadi (Lupiyoadi, 2013), promosi merupakan kegiatan yang dilakukan oleh sebuah perusahaan untuk mengkomunikasikan manfaat sebuah produk yang dibuat oleh perusahaan tersebut dan sebagai alat yang digunakan 
oleh perusahaan untuk mempengaruhi konsumen dalam kegiatan pembelian atau penggunaan jasa sesuai dengan kebutuhan. Promosi yang dilakukan agar seseorang tertarik untuk menggunakan OVO antara lain dalam bentuk voucher, cashback, discount dan lain-lain.

Berbagai studi mengenai faktor-faktor yang mempengaruhi keputusan penggunaan atau pembelian telah banyak dilakukan di berbagai wilayah di Indonesia. Genady (Genady, 2018) dalam penelitiannya menemukan bahwa variabel kemudahan, kemanfaatan dan promosi berpengaruh signifikan terhadap keputusan penggunaan uang elektronik baik secara parsial maupun simultan. Sari (Sari, 2018) dalam penelitiannya menemukan bahwa variabel gaya hidup mempunyai pengaruh terhadap keputusan penggunaan kartu kredit.

Rahayu, dkk (Rahayu et al., 2015) dalam penelitiannya menemukan bahwa variabel gaya hidup dan persepsi berpengaruh signifikan terhadap keputusan pembelian secara online di Kota Palembang secara parsial maupun simultan. Pratama (Pratama, 2015) dalam penelitiannya menemukan bahwa variabel gaya hidup, promosi dan kualitas produk berpengaruh signifikan terhadap keputusan pembelian secara parsial dan simultan. Ningsih (Ningsih, 2019) dalam penelitiannya menemukan bahwa persepsi dan kepercayaan berpengaruh berpengaruh signifikan terhadap keputusan menggunakan rekening ponsel secara parsial maupun simultan.

Setiani (Setiani, 2018) dalam penelitiannya menemukan bahwa persepsi kemanfaatan dan persepsi kemudahan tidak berpengaruh terhadap penggunaan alat pembayaran non tunai secara parsial. Variabel kepercayaan berpengaruh positif terhadap penggunaan alat pembayaran non tunai. Setyariningsih (Eny Setyariningsih, 2019) dalam penelitiannya menemukan bahwa gaya hidup berpengaruh secara parsial terhadap keputusan pembelian online. Variabel kepercayaan tidak berpengaruh secara parsial terhadap keputusan pembelian online. Secara simultan, gaya hidup dan kepercayaan berpengaruh terhadap keputusan pembelian.

Dari uraian di atas dapat diketahui masih banyaknya faktor-faktor yang mempengaruhi keputusan penggunaan serta masih belum konsistennya hasil penelitian terdahulu. Oleh karena itu, penulis tertarik untuk melakukan penelitian yang berjudul "Faktor-Faktor yang Mempengaruhi Keputusan Penggunaan OVO pada Mahasiswa Fakultas Ekonomi Universitas Negeri Yogyakarta".

\section{METODE}

Penelitian ini termasuk dalam penelitian asosiatif dengan pendekatan kuantitatif. Populasi yang digunakan dalam penelitian ini yaitu seluruh mahasiswa S1 Fakultas Ekonomi Universitas Negeri Yogyakarta angkatan 2016-2019 yang pernah dan sedang menggunakan OVO. Teknik pengambilan sampel dengan menggunakan purposive sampling dengan jumlah sampel sebanyak 250 orang. Ukuran sampel atau responden yang akan dijadikan sampel tesebut diperoleh dengan perhitungan rumus Hair et al (Hair et al., 2014) Rumus Hair et al merupakan rumus ukuran responden yang tergantung pada jumlah semua item pertanyaan dikalikan dengan 5-10. Pada 
penelitian ini, terdapat 50 pertanyaan. Batas minimal responden untuk penelitian ini yaitu $50 \times 5$ $=250$, sedangkan batas maksimalnya yaitu $50 \times 10=500$. Dengan demikian, responden yang akan diambil yaitu sebanyak 250 responden. Jumlah tersebut sudah dianggap dapat mewakili populasi yang akan diteliti karena sudah memenuhi batas minimal sampel. Teknik analisis data yang digunakan yaitu analisis regresi linier berganda. Teknik pengumpulan data menggunakan kuesioner. Instrumen penelitian yang digunakan diuji coba validitas dan reliabilitas terlebih dahulu dengan ringkasan hasil uji coba validitas dan reliabilitas pada tabel 1 dan 2 .

Tabel 1. Ringkasan Uji Validitas

\begin{tabular}{cc}
\hline Variabel & Hasil Uji Validitas \\
\hline Gaya Hidup & 0 item tidak valid \\
Persepi & 0 item tidak valid \\
Kepercayaan & 0 item tidak valid \\
Promosi & 0 item tidak valid \\
Keputusan Penggunaan OvO & 0 item tidak valid \\
\hline
\end{tabular}

Berdasarkan tabel di atas, hasil uji validitas instrumen semua item pernyataan pada semua variabel dinyatakan valid dan dapat digunakan dalam tahap penelitian selanjutnya.

Tabel 2. Ringkasan Uji Reliabilitas

\begin{tabular}{ccc}
\hline Variabel & Hasil Uji Reliabilitas & Keterangan \\
\hline Gaya Hidup & 0,780 & Tinggi \\
Persepi & 0,604 & Tinggi \\
Kepercayaan & 0,825 & Sangat Tinggi \\
Promosi & 0,851 & Sangat Tinggi \\
Keputusan Penggunaan OVO & 0,833 & Sangat Tinggi \\
\hline
\end{tabular}

Berdasarkan tabel di atas dapat disimpulkan bahwa kelima variabel mempunyai tingkat reliabel yang tinggi dan sangat tinggi, sehingga instrumen dinyatakan reliabel untuk digunakan dalam tahap penelitian selanjutnya.

\section{HASIL DAN PEMBAHASAN}

Uji asumsi klasik dilakukan sebelum uji hipotesis yang terdiri dari uji normalitas, uji linieritas, Uji multikolinieritas, dan uji heteroskedastisitas. Uji normalitas merupakan uji yang digunakan untuk mengetahui apakah data berbentuk distribusi normal atau tidak dan hasil nilai ujinya yaitu sig. yaitu 0,200>0,05 berarti data pada penelitian ini berdistribusi normal. Uji liniearitas digunakan untuk mengetahui apakah variabel bebas dan variabel terikat dalam penelitian memiliki hubungan 
linier dan hasil ujinya yaitu Sig. $>0,05$ berarti data bersifat linier. Uji multikolinieritas digunakan untuk melihat ada tidaknya hubungan yang sangat kuat atau sempurna antar variabel bebas dan hasil ujinya yaitu VIF $\leq 10$, tolerance $>0,10$ berarti tidak ada multikolinieritas. Uji heteroskedastisitas digunakan untuk menguji apakah di dalam model regresi yang digunakan terjadi ketidaksamaan variance dari residual sebuah pengamatan ke pengamatan yang lainnya dan hasil ujinya yaitu Sig. $>0,05$ berarti tidak terjadi heteroskedastisitas. Oleh karena itu, persyaratan uji analisis regresi linier berganda terpenuhi. Hasil analisi regresi linier berganda yang dilakukan terlihat pada tabel 3 .

Tabel 3. Hasil Analisis Regresi Linier Berganda

\begin{tabular}{cccc}
\hline Variabel & Koefisien Regresi & t-hitung & Sig. $\mathbf{~}$ \\
\hline Gaya Hidup & 0,174 & 3,137 & 0,002 \\
Persepsi & 0,343 & 3,477 & 0,001 \\
Kepercayaan & 0,340 & 5,923 & 0,000 \\
Promosi & 0,261 & 4,739 & 0,000 \\
\hline
\end{tabular}

$$
\begin{aligned}
& \text { Konstanta }=4,529 \\
& \mathbf{R}=0,679 \\
& \mathbf{R} \text { square }=0,461 \\
& \text { Fhitung }=51,321
\end{aligned}
$$

Sig. $F=0,000$

Berdasarkan hasil analisis diatas dapat dihasilkan persamaan regresi linier berganda sebagai berikut:

$$
\mathrm{y}=4,529+0,174 \mathrm{X} 1+0,343 \mathrm{X} 2+0,340 \mathrm{X} 3+0,261 \times 4
$$

Hasil perhitungan uji statistik $\mathrm{t}$ atau uji parsial menunjukkan bahwa variabel gaya hidup memiliki koefisien regresi sebesar 0,174, Sig. 0.002<0,05, t-hitung >t-tabel $(3,137>1,651)$. Berdasarkan hal tersebut dapat disimpulkan bahwa variabel gaya hidup berpengaruh positif dan signifikan terhadap keputusan penggunaan OVO pada mahasiswa Fakultas Ekonomi Universitas Negeri Yogyakarta sehingga hipotesis pertama $\left(h_{a 1}\right)$ dalam penelitian ini diterima.

Hasil penelitian ini sejalan dengan penelitian yang dilakukan oleh Sari (Sari, 2018) yang menunjukkan hasil bahwa gaya hidup berpengaruh signifikan terhadap keputusan penggunaan kartu kredit. Dengan demikian, hasil penelitian ini mendukung penelitian sebelumnya. Gaya hidup individu yang semakin mengikuti perubahan zaman atau semakin tinggi akan menyebabkan seseorang memutuskan penggunaan untuk layanan atau produk untuk mengikuti perubahan zaman tersebut. Semakin tinggi gaya hidup seseorang maka keputusan penggunaan OVO akan semakin tinggi.

Hasil perhitungan uji statistik $\mathrm{t}$ atau uji parsial menunjukkan bahwa variabel persepsi memiliki koefisien regresi sebesar 0,343, Sig. $0.001<0,05$, t-hitung $>$ t-tabel $(3,477>1,651)$. 
Berdasarkan hal tersebut dapat disimpulkan bahwa variabel persepsi berpengaruh positif dan signifikan terhadap keputusan penggunaan OVO pada mahasiswa Fakultas Ekonomi Universitas Negeri Yogyakarta sehingga hipotesis kedua $\left(\mathrm{h}_{\mathrm{a} 2}\right)$ dalam penelitian ini diterima.

Hasil penelitian ini sejalan dengan penelitian yang dilakukan oleh Ningsih (Ningsih, 2019) yang menunjukkan hasil bahwa persepsi berpengaruh signifikan keputusan menggunakan rekening ponsel Bank CIMB Niaga. Dengan demikian, hasil penelitian ini mendukung hasil penelitian sebelumnya. Persepsi individu terkait suatu layanan atau produk itu tinggi maka keputusan untuk menggunakan suatu layanan atau produk juga akan semakin tinggi. Semakin tinggi persepsi individu terhadap layanan ata produk OVO maka akan semakin tinggi tinggi keputusan untuk menggunakan OVO.

Hasil perhitungan uji statistik t atau uji parsial menunjukkan bahwa variabel kepercayaan memiliki koefisien regresi sebesar 0,340, Sig. $0.000<0,05$, t-hitung $>$ t-tabel $(5,923>1,651)$. Berdasarkan hal tersebut dapat disimpulkan bahwa variabel kepercayaan berpengaruh positif dan signifikan terhadap keputusan penggunaan OVO pada mahasiswa Fakultas Ekonomi Universitas Negeri Yogyakarta sehingga hipotesis ketiga $\left(h_{a 3}\right)$ dalam penelitian ini diterima.

Hasil penelitian ini sejalan dengan penelitian yang dilakukan oleh Setiani (Setiani, 2018) yang menunjukkan hasil bahwa variabel kepercayaan berpengaruh positif dan signifikan terhadap penggunaan alat pembayaran non tunai secara parsial. Dengan demikian, hasil penelitian ini mendukung hasil penelitian sebelumnya. Kepercayaan terhadap suatu layanan atau produk dapat membuat seseorang tertarik melakukan keputusan penggunaan layanan atau produk. Semakin besar kepercayaan terhadap produk OVO maka keputusan penggunaan OVO akan semakin besar pula.

Hasil perhitungan uji statistik $t$ atau uji parsial menunjukkan bahwa variabel promosi memiliki koefisien regresi sebesar 0,261, Sig. $0.000<0,05$, t-hitung $>$ t-tabel $(4,739>1,651)$. Berdasarkan hal tersebut dapat disimpulkan bahwa variabel promosi berpengaruh positif dan signifikan terhadap keputusan penggunaan OVO pada mahasiswa Fakultas Ekonomi Universitas Negeri Yogyakarta sehingga hipotesis keempat $\left(h_{a 4}\right)$ dalam penelitian ini diterima.

Hasil penelitian ini sejalan dengan penelitian yang dilakukan oleh Genady (Genady, 2018) yang menunjukkan hasil bahwa variabel promosi berpengaruh secara signifikan terhadap keputusan penggunaan secara parsial. Dengan demikian, hasil penelitian ini mendukung hasil penelitian sebelumnya. Promosi yang menarik dan bagus terkait OVO dapat menarik seseorang untuk melakukan keputusan penggunaan OVO. Semakin menarik promosi terkait OVO maka keputusan penggunaan OVO akan semakin tinggi.

Hasil perhitungan secara simultan atau bersama-sama pengaruh gaya hidup, persepsi, kepercayaan, dan promosi terhadap keputusan penggunaan OVO memilki nilai signifikansi 0,000, Fhitung $>$ Ftabel $(51,321>3,879)$. Berdasarkan hal tersebut dapat disimpulkan bahwa gaya hidup, persepsi, kepercayaan, dan promosi berpengaruh positif dan signifikan secara simultan terhadap 
keputusan penggunaan OVO pada Mahasiswa Fakultas Ekonomi Universitas Negeri Yogyakarta sehingga hipotesis kelima $\left(\mathrm{h}_{\mathrm{a} 5}\right)$ dalam penelitian ini diterima.

Hasil penelitian ini juga menunjukkan hasil nilai koefisien determinasi (R Square) sebesar 0,461. Hal ini berarti keempat variabel bebas yaitu gaya hidup, persepsi, kepercayaan, dan promosi memiliki pengaruh sebesar $46,1 \%$ terhadap keputusan penggunaan OVO. Sisanya sebesar $53,9 \%$ dipengaruhi oleh faktor lain yang tidak diteliti dalam penelitian ini.

\section{SIMPULAN}

Berdasarkan hasil dan pembahasan diatas dapat disimpulkan bahwa penelitian ini mempunyai hasil yaitu bahwa variabel gaya hidup, persepsi, kepercayaan, dan promosi berpengaruh positif dan signifikan terhadap keputusan penggunaan OVO pada mahasiswa Fakultas Ekonomi Universitas Negeri Yogyakarta baik secara parsial maupun simultan. Hal ini menunjukkan bahwa hipotesis yang ada dalam penelitian ini baik hipotesis pertama $\left(\mathrm{h}_{\mathrm{a} 1}\right)$, hipotesis kedua $\left(\mathrm{ha}_{\mathrm{a} 2}\right)$, hipotesis ketiga $\left(h_{a 3}\right)$, hipotesis keempat $\left(h_{a 4}\right)$, hipotesis kelima $\left(h_{a 5}\right)$ penelitian ini diterima.

Dalam penelitian ini tentu masih ada keterbatasannya. Oleh karena itu, penelitian selanjutnya disarankan untuk mencakup responden yang lebih luas tidak hanya mahasiswa Fakultas Ekonomi Universitas Negeri Yogyakarta saja. Selain itu, faktor yang dapat mempengaruhi keputusan penggunaan OVO lebih dikembangkan lagi tidak hanya faktor yang ada dalam penelitian ini misalnya faktor pada teori TAM, teori UTAUT, dan lain sebagainya.

\section{DAFTAR PUSTAKA}

APJII. (2019). Hasil Survei Penetrasi dan Perilaku Pengguna Internet Indonesia 2017. In Asosiasi Penyelenggara Jasa Internet Indonesia.

Aria, P. (2019). OVO Jadi Dompet Digital Terbesar di Indonesia Berkat Ekosistem Grab Artikel ini telah tayang di Katadata.co.id dengan judul "OVO Jadi Dompet Digital Terbesar di Indonesia Berkat Ekosistem Grab" , https://katadata.co.id/pingitaria/digital/5e9a4e6c28da0/ovo. https://katadata.co.id/pingitaria/digital/5e9a4e6c28da0/ovo-jadi-dompet-digital-terbesardi-indonesia-berkat-ekosistem-grab

Bank Indonesia. (2018). Peraturan Bank Indonesia tentang Uang Elektronik.

Bank Indonesia. (2020). Informasi Perizinan Penyelenggara dan Pendukung Jasa Sistem Pembayaran. Bank Indonesia. https://www.bi.go.id/id/sistem-pembayaran/informasi-perizinan/uangelektronik/penyelenggara-berizin/Contents/Default.aspx

Bothun, D., Glisson, S., Haas, R., Issac, C., \& Lieberman, M. (2013). Consumer Intelligence Series: Opening the Mobile Wallet. PricewaterhouseCoopers LLP.

Eny Setyariningsih. (2019). Pengaruh Gaya Hidup dan Kepercayaan terhadap Keputusan 
Pembelian Online (E-Commerce) Lazada di Kota Mojokerto. The Journal of Business and Management.

Genady, D. I. (2018). Pengaruh Kemudahan, Kemanfaatan, Dan Promosi Uang Elektronik Terhadap Keputusan Penggunaan Uang Elektronik Di Masyarakat (Studi Kasus di Provinsi DKI Jakarta). In Skripsi.

Hair, J. F., Black, J. W. C., Babin, B. J., \& Anderson, R. E. (2014). Multivariate Data Analysis: Seventh Edition. In Pharmaceutical Quality by Design: A Practical Approach. https://doi.org/10.1002/9781118895238.ch8

Kotler dan Amstrong. (2013). Prinsip-Prinsip Pemasaran Jilid I. In Erlangga.

Kotler, P., \& Keller, K. L. (2009). Manajemen pemasaran Jilid 1. In Jakarta.

Lupiyoadi, R. (2013). Manajemen Pemasaran Jasa: Berbasis Kompetensi Edisi 3. Penerbit Salemba.

Mowen, john C., \& Minor, M. (2002). Prilaku konsumen. Jakarta: Erlangga. https://doi.org/10.1016/j.materresbull.2010.09.021

Ningsih, A. U. (2019). Pengaruh Persepsi dan Kepercayaan terhadap Keputusan Menggunakan Rekening Ponsel Bank CIM Niaga Syariah (Studi Kasus Wilayah Tangerang Selatan). UIN Syarif Hidayatullah.

Pratama, A. K. (2015). Analisis Pengaruh Gaya Hidup, Promosi, dan Kualitas Produk terhadap Keputusan Pembelian Smartphone Samsung (Studi Kasus pada Konsumen Smartphone Samsung Wilayah Jakarta Pusat). UIN Syarif Hidayatullah.

Rahayu, S., Zuhriyah, Z., \& Bonita, S. (2015). PENGARUH GAYA HIDUP DAN PERSEPSI MAHASISWA TERHADAP KEPUTUSAN PEMBELIAN SECARA ONLINE DI KOTA PALEMBANG. Jurnal Manajemen Dan Bisnis Sriwijaya. https://doi.org/10.29259/jmbs.v13i3.3374

Saputra, R., \& Semuel, H. (2013). Analisa Pengaruh Motivasi, Persepsi, Sikap Konsumen Terhadap Keputusan Pembelian Mobil Daihatsu Xenia di Sidoarjo. JURNAL MANAJEMEN PEMASARAN

Sari, D. P. (2018). Pengaruh Periklanan, Promosi Penjualan, Public Relation, Personal Selling, Direct Selling, dan Gaya Hidup (Life Style) terhadap Keputusan Pembelian Telkomsel Cash (T-Cash) (Studi Kasus pada Mahasiswa Fakultas Ekoomi dan Ilmu Sosial UIN SUSKA Riau). UIN SUSKA Riau.

Setiani, R. (2018). Faktor-Faktor yang Mempengaruhi Penggunaan Alat Pembayaran Non Tunai (Studi di Kota Purbalingga). Universitas Islam Indonesia.

Solomon, M. R. (2012). Consumer Behavior: Buying, Having, Being. In Consumer behavior. 
Faktor-Faktor yang .... (Rinda Novitasari) 